Table 2. Teeming conditions.

\begin{tabular}{l|c|c|c|c|c}
\hline \hline Ingot & $\begin{array}{c}\text { Teeming atmos- } \\
\text { phere }\end{array}$ & Tapping tmp. $\left({ }^{\circ} \mathrm{C}\right)$ & Killing time & Teeming time & Teeming temp. $\left({ }^{\circ} \mathrm{C}\right)$ \\
\hline B E A C & Open air & 1605 & $4^{\prime} 55^{\prime \prime}$ & $15^{\prime} 15^{\prime \prime}$ & $1524 \sim 1515$ \\
B E V C* & Vacuum & 1642 & $7^{\prime} 10^{\prime \prime}$ & $7^{\prime} 07^{\prime \prime}$ & $1561 \sim 1555$ \\
A A C & Open air & 1580 & $30^{\prime} 51^{\prime \prime}$ & $15^{\prime} 12^{\prime \prime}$ & $1502 \sim 1490$ \\
\hline
\end{tabular}

* Hot topping was aided by electric arc heating.

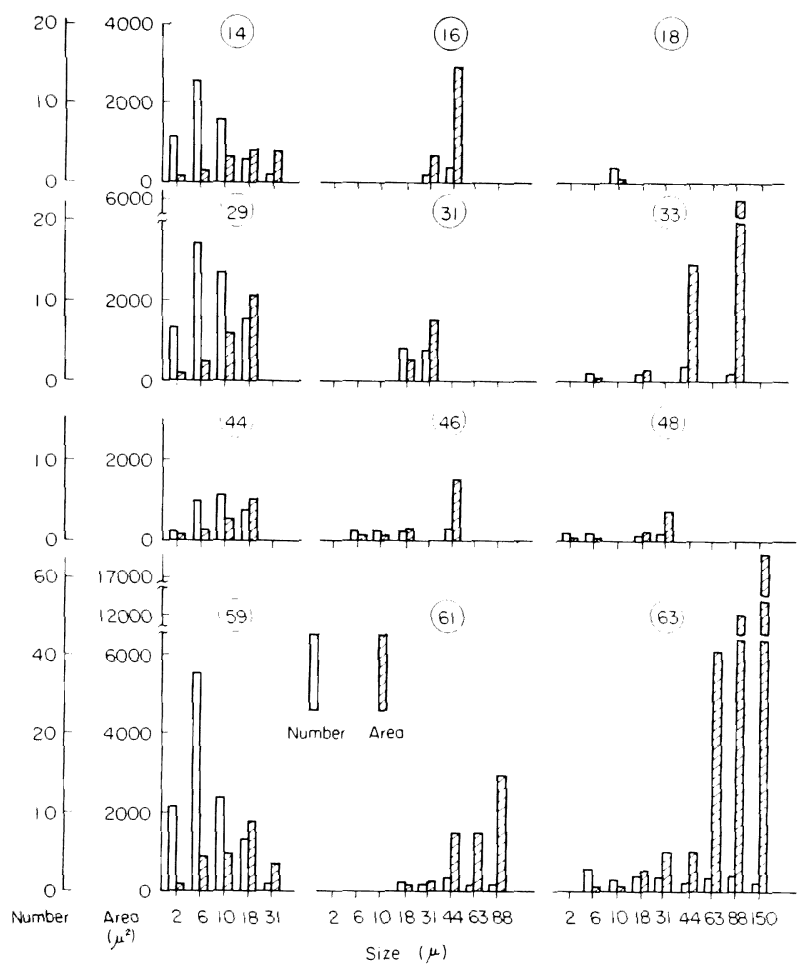

Fig. 4. Distribution of Type II inclusions in the AOAC steel ingot. (no. corresponds to the sampling position.)
また酸化物は BEAC および AOAC 鋳塊においては Type III が多く, BEVC 鋳塊では Type II が多い。こ れは酸化物相中の $\mathrm{MnO}$ 成分の量のちがいによるものと 考元られる。すなわち温硝酸法による酸化物の定量結果 に扔いて，BEVC 鋳塊では $\mathrm{Al}_{2} \mathrm{O}_{3}$ 成分が $93 \%$ 以上を しめ，残りが $\mathrm{SiO}_{2}$ 成分であるのに対して，ほかの2 鋳 塊においては $\mathrm{Al}_{2} \mathrm{O}_{3}$ 成分が非常に少なく7〜8\% であ り， $\mathrm{MnO}$ 成分が 20 ３0\% も含まれており，残りがお もに $\mathrm{SiO}_{2}$ 成分である。また EPMAによる個々の酸化 物の分析結果に扔いても大気鋳造の 2 鋳塊では $\mathrm{MnO}$ 成 分が多い. AOAC 鋳塊においてはほかの鋳塊にくらべ て傎偏析部の大型酸化物が多かつた。これはTable 2 に 示したように注入温度が比較的に低かつたことに起因す るものと考息られる。ま $\mathrm{AOAC}$ 鋳塊の大型酸化物は 比較的に低融点のものである。これが溶製造塊条件とど のように関連しているかをあきらかにするのは今後に残 された問題であろう。

本実験におけるような観察を継続して結果を集積し，
大型鋳塊内における介在物の分布状態を握把 し，鋼の組成および㠜固条件を適宣選択するこ とにより, 介在物の分布状態をある程度統御し うるようになるものと考えられる。

\section{5. 結言}

1) 溶製方法および造塊条件のちがいによ二 て各種介在物の分布傾向にはかなり差が認め巨 れる、真偏析部の酸化物の量におよぼす注入沿 度の影響はかなり大きいようである。

2 ）真空鋳造を適用することにより酸化物。 量はかなり減少し, その形も結晶状のものが多 くなる。

3）硫化物の分布傾向も造塊条件によつて力 なりの影盟をうける。

\section{交献}

1) 菅野, 成田，他：鉄と鋼，50（1964）, p. 1770

\section{$20 \mathrm{t}$ 炭素鋼鋳塊の凝固速度と鋳塊 内部組織に関する 2,3 の所見*}

(塩基性電弧炉抢よび酸性平炉溶製の

大型鍛鋼材に関する比較検討ならびに 真空鋳造に関する研究-N)

神戸製鋼所中央研究所

理博, 工博 成田 貴一・宮本 醇 小山伸二. 石井輝雄

$$
\text { 機械事業部齐藤千弓 }
$$

Some Views of Freezing Rate and Internal Structure of 20t Carbon Steel Ingot (Study on specifications of heavy steel forgings made by basic electric arc furnace and acid open hearth furnace as well as investigations on vacuum. casting-- N )

Dr. Kiichi Narita, Jun MiYamoto

Shinji Koyama, Teruo Ishin and Chiyumi SaIto

$$
\text { 1. 緒言 }
$$

鋳塊の㠜固速度あるいは凝固過程における鋳塊内部。 温度变化を知ることは，内部組織の健全な鋳塊を造る十 めの製造技術的な立場あるいは生産能率を上げるため。 生産工程管理の立場から考えても重要なことである。 のためには従来から種々の実測方法あるいは伝熱方程至

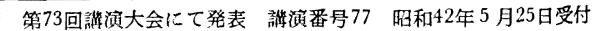


の数学的解析, 図式解法あるいは数値解法などの方法が とられてきた。しかしながらこれらの方法によつてもか ならずしも満足な結果はえられていない，一方最近の電 子計算機の発達にともなつて鋳塊凝固時の温度変化の数 俌計算に電子計算機を利用した結果もいくつか報告され

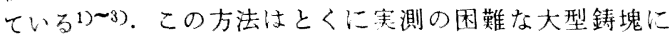
对して有効な手段である.本報告では一次元の伝熱方程 式にもとついて $20 \mathrm{t}$ 鍛造用鋳塊の凝固時の温度変化を 計算し，凝固速度を求めた結果をかえたえに報告し，鋳 塊内部組織につい 2,3 ての所見をのベる。

\section{2. 計 算 方 法}

計算は熱伝導の偏微分方程式を差分方程式にかきかえ ておこなうのであるが，その差分表示にはいくつかの方 法があるがここでは SARJANT と SLACKによる方法》を もちいた，計算の対象とした鋳塊は鍛造用の $20 \mathrm{t}$ 16角 波型鋳塊であるが，それを队筒形で近似すると鋳塊の半 径方向の熱伝導は（1）式で表わせる.

$$
C \cdot \rho \frac{\partial \theta}{\partial t}=\frac{\partial}{\partial r}\left(K \frac{\partial \theta}{\partial r}\right)+\frac{K}{r} \frac{\partial \theta}{\partial r}
$$

ここで, $\theta$ : 温度, $t$ : 時間, $r$ : 半径, $C$ : 此熱, $K:$ 熱伝導率, $\rho:$ 密度

$C$ および $K$ を温度の関数としてとり扱うために（2）式 で示される特性温度 $\phi$ 導入する. (2) 式の関係と比

$$
\phi=\int_{\theta_{d}}^{\theta}\left(K / K_{d}\right) d \theta
$$

$K_{d}$ : ある任意温度 $\theta_{d}$ における熱伝導率, 熱に関して $C=\partial H / \partial \theta$ ( $H$ : 含熱量）の関倸式をもちい ると（1）式は結局（3）式のようにかきかえられる.

$$
\frac{\hat{O} H}{\partial t}=\frac{K_{d}}{\rho}\left(\frac{\partial^{2} \dot{\phi}}{\partial r^{2}}+\frac{1}{r} \frac{\partial \phi}{\partial r}\right)
$$

この（3）式を（4）式に示した差分片程式で近似し，

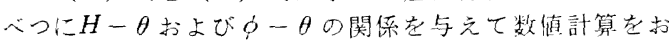
こなう。

$$
\begin{aligned}
& \frac{H_{n, t+} J_{t}-H_{n, t}}{J t}=\frac{K_{d}}{\rho} . \\
& \left\{\left(\frac{\phi_{n+1}, t-2 \phi_{n, t}+\phi_{n-1, t}}{\left(J_{r}\right)^{2}}\right)\right. \\
& \left.\quad+\frac{1}{r_{n}} \cdot \frac{\phi_{n+1}, t-\phi_{n-1, t}}{2 J r}\right\}
\end{aligned}
$$

ここて $J t$ : 時間分割, $J r$ : 距離分割, $r_{n}$ : 距離座標 の原点（鋳塊中心）から第 $n$ 番目の格子点までの距離で

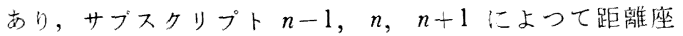
標

初期条件：初期条件すな⿰ち一鋳込直後の鋳塊と鋳型の 境界面の温度は ( 5 ) 式の関倸から求的る。

$$
\left.\begin{array}{c}
\delta \theta_{S}+\hat{o}_{s M}=(\text { 鋳込温度 })-(\text { 鋳型の初期温度 }) \\
\sqrt{\frac{K_{M} \cdot \tau}{C_{M} \cdot \rho_{M}}} \cdot \rho_{M} \cdot C_{M} \cdot \delta \theta_{M}=\sqrt{\frac{K_{S} \cdot \tau}{C_{S} \cdot \rho_{S}}} \cdot \\
\rho_{S}\left(C_{S} \cdot \delta \theta_{S}+L\right)
\end{array}\right\}
$$

ただし, $\delta \theta_{M}$ : 鋳型と境界面の温度の差, $\delta \theta_{S}:$ 鋳込 温度と境界面の温度の差, $\tau: \Delta t$ よりも十分短い時間, $K_{M}, C_{M}, \rho_{M}$ : 鋳型の熱伝導萃, 比熱および密度, $K_{S}$, $C_{S}, \rho_{S}$ : 鋳塊の熱伝導率, 比熱および密度, $L$ : 鋳塊の 凝固潜熱,

境界条件：鋳塊と鋳型の境界ではいわゆる空陌が形成
されるまでは伝導による熱伝達を，空煊形成後はふく射 による熱伝達を考えてえれぞれ（6）式および（7）式 の關係をもちいる。

空隍形成前: $d H_{M}=C_{M} \cdot d \theta$

$$
d H_{S}=C_{S} \cdot d \theta
$$

ただし， $H_{M}, H_{S}$ : 鋳型および鋳塊の含熱量

空腙形成後:

$$
Q=q_{S}-q_{M}=\sigma \cdot \frac{\varepsilon_{M} \cdot \varepsilon_{S}}{\varepsilon_{M}+\varepsilon_{S}-\varepsilon_{M} \cdot \varepsilon_{S}}\left(T_{S}{ }^{4}-T_{M}{ }^{4}\right)
$$

ただし，Q：境界面に打ける伝熱量， $\sigma:$ Stefan 定数, $\varepsilon_{M}, \varepsilon_{S}$ : 鋳型および鋳塊面のふく射率, $T_{S}, T_{M}$ : 鋳塊 表面および鋳型内面の絶対温度.

鋳型表面から周囲人は空気の対流による熱伝達と示く 射による熱伝達とを考えて（8）式の関倸をもちいる.

$$
W=\alpha_{a}\left(\theta_{M}-\theta_{a}\right)+\sigma \cdot \varepsilon_{M}\left(T_{M}^{4}-T_{a}^{4}\right) \cdots \cdots \cdots(8)
$$

ただし，W: 鋳型表面から周囲一の伝熱量, $\theta_{M}\left(T_{M}\right)$, $\theta_{a}\left(T_{a}\right)$ ；鋳型表面および周囲の温度 (絶対温度), $\alpha_{a}$; 自然対流による熱伝達係数であり，鋳型を長い内筒とみ なすとつきの式で与えられる。

$$
\alpha_{a}=1 \cdot 1\left\{\left(\theta_{M}-\theta_{a}\right) / D\right\}^{0 \cdot 25}
$$

だ゙し， $D$ ：鋳型の外径, $\alpha_{a}:\left(\mathrm{kcal} / \mathrm{m}^{2} \cdot \mathrm{hr} \cdot \mathrm{C}\right)$ 計算に際しては $K$ および $C$ は温度の関数として, $\rho$ は定 数としてとり扱つた。時間分割 $J t=2 \mathrm{~min}$, 距離分割 $J r$ は鋳塊ではおおょ二 65〜 70 $\mathrm{mm}$ とし，鋳型では68〜80 $\mathrm{mm}$ とした。な掞鋳型内溶鋼の対流はないものとして計 算をおこなつた。

\section{3. 計算結果および検討}

計算に必要な諸物性值が比較的よく与えられている1 $\% \mathrm{Cr}-0.5 \%$. Mo 鋼を対象として $20 \mathrm{t}$ 鋳塊について, 鋳 込温度，鋳型温度，鋳型壁厚および鋳塊と鋳型間の空隚 形成時間を 2 . 3 变えてまず計算をおこなつた。錆塊お よび鋳型の温度変化の1例を Fig. 1 に示す。ここで問 題になるのは鋳込後数分経過すれば瞬間的に空隚ができ したがつて鋳塊と鋳型境界での伝熱量が不連続に変化す ると考无ているので空隚形成直後に鋳塊表面の温度は急 速に上かり，鋳型内面の温度は急速に下がつていること である. $20 \mathrm{t}$ 程度の大型鋳塊に执いて鋳込㣪数分程度で 瞬間的に空隚ができると考えることには問題があり，実 際には何分間かにわたつてじよじよに空隙がひろがり， したがつて二の間の伝熱量もほ匡連続的に変化すると考 えるのが妥当であろう。ただ空隚形成時間在たとえは 4 $\min$ から $10 \mathrm{~min}$ 程度に变元ても凝固時間市るい:鋳记 後ある程度時間が経過したのちの温度変化にはあまり大 きな変化はないししたがつて，たとえば鋳込条件のよう なある因子の影然を比較する場合には空隙形成時間をか んたえに仮定してもさしつかえないと考えられる。また 従来より溶鋼の過熱度（鋳込温度一液相線温度の差）は 対流なよに上り鋳迟後比較的に短時間でなくなるといわ れているが，本計算では対流を考㫕ていないので比較的 に長時間まで溶鋼内部の温度は高いままである。ただ寒 際の鋳塊で押湯の保温あるいは押湯加熱を孔こなつてい る場合にはたとえ対流があるとしても熱的には凝固時の 温度变化に対する過熱度の影管考考虑しておく必要があ る。 


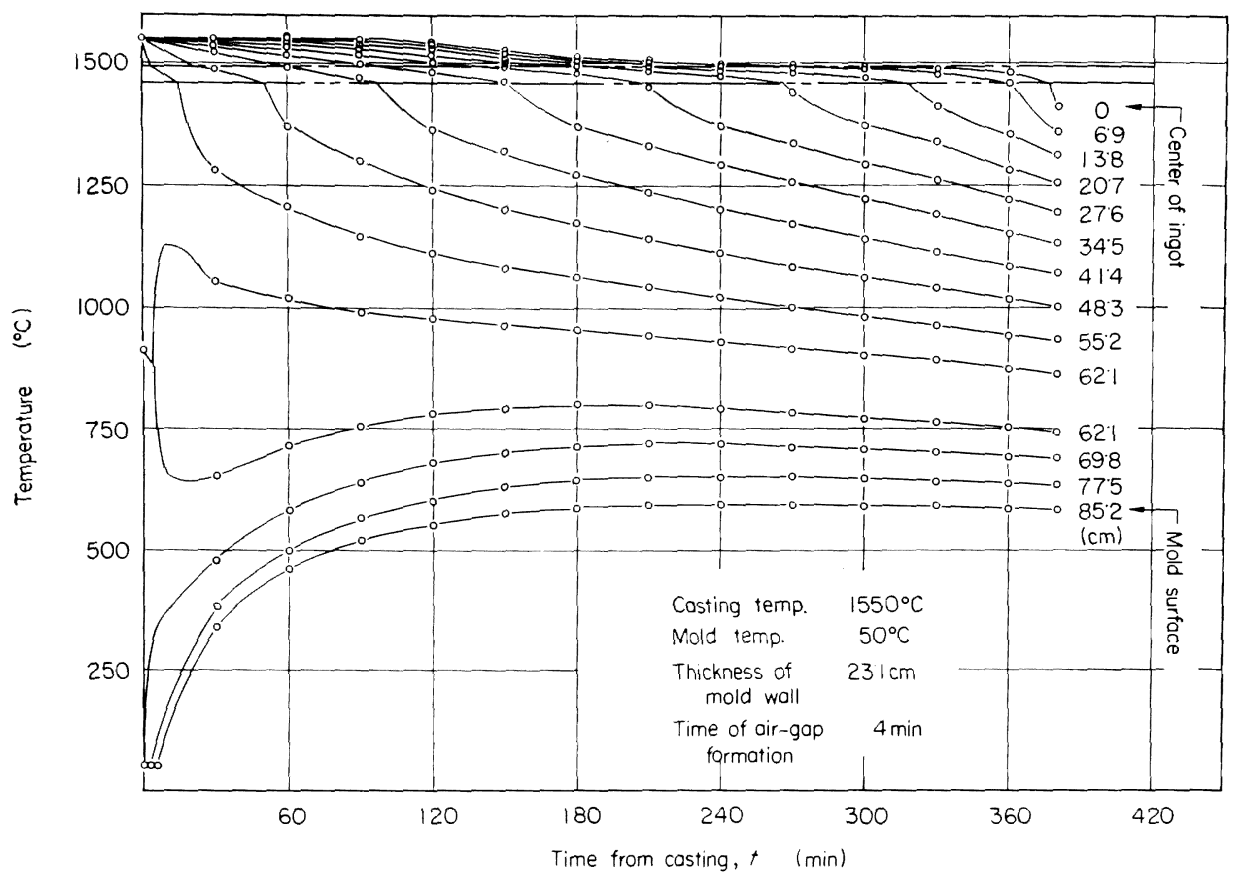

Fig. 1. Temperature variation at different parts in ingot and mold during solidification.

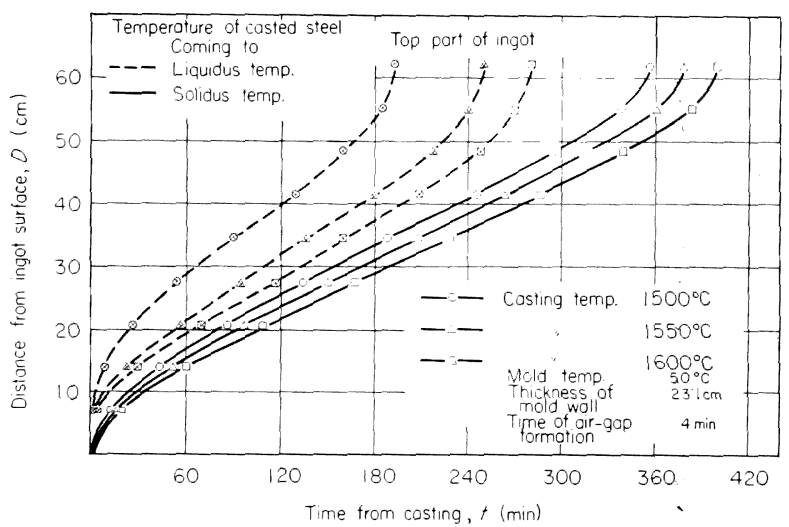

Fig. 2. Solidification curve of 20ton $\mathrm{Cr}-\mathrm{Mo}$ steel ingot.
固相とが共存する状態，いわゆる mushy state が存在することがうかがえる・一方液相線なら びに固相線温度に達する時間は，たとえば鋳型 の初期温度を $50^{\circ} \mathrm{C}$ から $100^{\circ} \mathrm{C}$ に变えた場合に は 1〜 $5 \mathrm{~min}$ 程度遅くなり，鋳型の壁厚を $23 \cdot 1$ $\mathrm{cm}$ から $30.8 \mathrm{~cm}$ に变光た場合には1〜10 min 程度早くなり，空隙形成時間を $4 \mathrm{~min}$ から 10 $\min$ に変えた場合で $1 \sim 7 \mathrm{~min}$ 程度早くなる。 いずれの因子の影響もかなり大巾に变えないか ぎりそれ程大きなものではないことがわかる。 実操業の造塊条件において变えうる籁囲老考虑 した場合に熱的な意味で鋳塊の凝固にもつとも 影響を与えるのは鋳込温度であると考元られ る.さきにのべたように，鋳型内の溶鋼中に対 流が存在するとしても押湯の保温あるいは加熱 をおこなつている場合にはこの鋳込温度の影響

Fig. 1 に示した結果より鋳塊内の各位置の温度が液相 線温度ならびに固相線温度に達する時間を求めると Fig. 2 红示す結果がえられる. 同図には鋳込温度を变えた場 合の結果をあわせて示してある.ここで固相線温度に達 した時点を凝固が完了した時間とみなすと, 凝固式 $D=$ $a \cdot \sqrt{t}$ の関係が成立するのは $D=15 \sim 20 \mathrm{~cm}$ の位置まで であり，无れ以後は凝固艻速くなり $D$ と $t$ との関係はむ しろ直線関係に近くなる。そして鋳塊中心近くでさらに 凝固が加速される.実際の鋳塊で底部側からの凝固を考 慮すると同図の㠜固曲線の㣪半部ではさらに㠜固が加速 されると考えられるが，すくなくとも前半部はこの半径 方向の凝固が優先すると考えられる. また鋳込後かなり 早い時期から鋳塊内のかなり広い籁囲にわたつて液相と
は無視できない。

さて前報5)において鍛造用 $20 \mathrm{t}$ 炭素鋼 (S45G) 鋳 塊について塩基性電弧炉溶製の大気中鋳造鋳塊( B E A C 鋳塊) および真空鋳造鋳塊（B E V C 鋳塊）ならびに 酸性平炉溶製の大気中鋳造鋳塊（AOA C 鋳塊）の内部 性状の比較をおこなつたが，この3 鋳塊の造塊条件でと くに相異していたのは鋳込温度であつた，この点考虑 して鋳塊の凝固曲線を求めた結果を Fig. 3 に示す. こ の結果より鋳塊内各位置において液相線と固相線間の温 度範囲（液相と固相とが共存する範囲）に滞留する時間 を求めると Fig. 4 に示したとおりである.ここでは半 径方向の伝熱のみを考えているので実際の鉡塊の中心部 付近ではこの結果とは異なるであろうが，いずれにして 


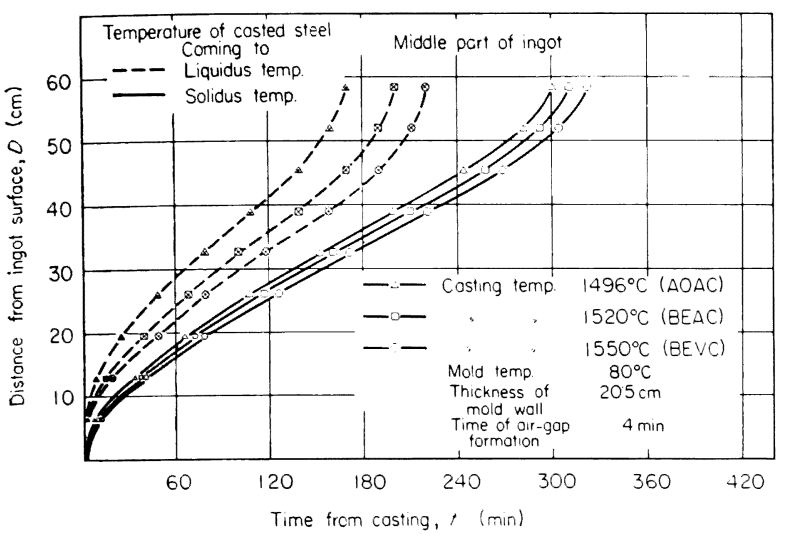

Fig. 3. Solification curve of 20ton carbon steel ingot.

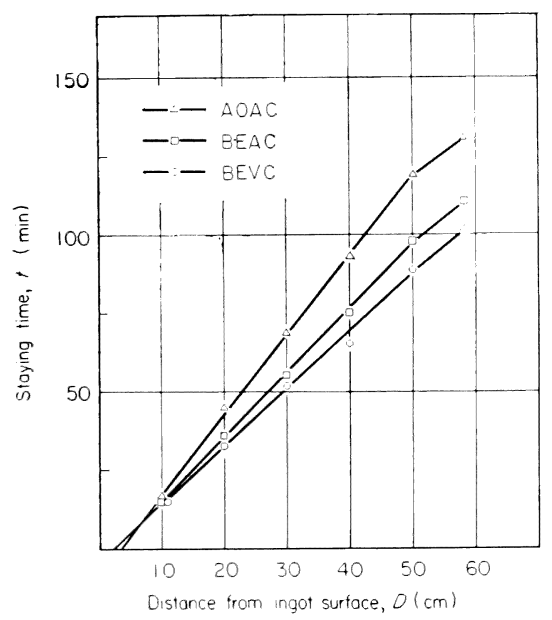

Fig. 4. Staying time of casted steel in temperature range between liquidus and solidus line.

も鋳込温度の低いAOA C 鋳塊では鋳塊表面部付近から mushy state になる時間が長いと考えられる。これは鋳 込温度が低いと凝固の開始は早くなり，てれにともなう 凝固潜熱の発生によつて浟固の完了が相対的に潍れてく ることに原因するものと考えられる。一方鋳塊内部組織 の観察結果ではいわゆる等軸晶域の占める割合は A O A C 鋳塊がもつとも大きく, ついで B E V C 鋳塊, B E A $\mathrm{C}$ 鋳塊の順に小さくなつている。云れとともに逆 $\mathrm{V}$ 偏析 も AO A C 鋳塊では鋳塊のより表面部付近から存在する ことが認められている。このことは現象的には鋳込温度 が低い場合に mushy state の存在範囲が広がることに原 因するものと考えられる。また鋳込温度のみの影留で考 えると B E A C 鋳塊と B E V C 鋳塊とでは現象が逆にな つているが，これは BEAC 鋳塊では平均して $\mathrm{S}$ 量が 0.021\%，P量が 0.048\% でありほかの 2 鋳塊にくらバ てほほ倍程度であることに原因するものと考えられる。 等軸晶の生成機䓯についてはま隹にらかでなく，いわゆ る組成的過冷却現象にもとづく説明己定性的なものにす
ぎず，やはり問題が残る。とくに大型鋳塊では 結晶核生成の問題はあるけれども結晶の沈降現 象も否定するこをはできないと考えられる。い ずれにしてもいわゆる mushy state の性状を 明らかにすることがまず必要であろう。

\section{4. 結}

言

一次元の熱伝導方程式にもとづいて鋳塊の凝 固時の温度変化ならびに凝固速度を計算した。 その結果害操業時の造塊条件の变えうる篹囲を 考虑した場合に，熱移動の立場からは鋳塊の凝 固に対して鋳込温度の影響がもつとも大きいと 考えられる.

さきに報告した $20 \mathrm{t}$ 炭素鋼鋳塊の内部組織 については鋳込温度の相異による影噌が重要で あることを示した。

\section{交献}

1) 千原，田阔：日本鋼管技報，22 (1961)，p. 246

2 ) J. Schniewind: J. Iron \& Steel Inst.(U.K.), 201 (1963), p. 594

3 ) J. G. Henzfl JR and J. Keverian: J. of Metals, 17 (1965), p. 561

$4) R . J$. Sarjant and $M . R$. Slack: J. Iron \& Steel Inst. (U.K.), 177 (1954), p. 428

5 ) 菅野, 成田, 宮本, 小山, 長谷場, 鈴木: 鉄と鋼，50 (1964)，p. 1770

\section{転炉炉内測温と分析による吹止温度， C 制御について*}

神戸製鋼，尼崎工場

藤井 成美・林正照

On the End Point Temperature and Carbon Control with Dropping Thermocouple and Carbon Detector in the Molten Bath of L. D. Converter during Blowing

Shigeyoshi FujII and Masateru HAYAshI

\section{1. 緒}

\section{言}

1963年 2 月尼崎工場の $30 \mathrm{t}$ 純酸素転炉汇富土通製コ ソピニーター, FIDAP-400A（第1 号機）が入荷し, 二 の後 1 力年にわたる試運転期間を経，転炉操業実績の集 積と解析に努沙, 現在吹止温度, C の予測計算制御老実 施中でその概要は一部既報のとおりである1).

現在吹止温度，Cの計算制御のために採用されている 数式モデルの基本式は（1）式のとおりで，これは1963 年に開発光机た「現, 前鋼番操業变数の差の導入によつ て計測値，未計測值の誤差を自動的に消去する方式」と して著しい成果を示している2゙.

当工場ではこの他に㞹の特性, 操業の諸条件を考虑し 「現，前銅番入力值の重み老必ずしも一定としない(2) 式」も採用して予測精度の向上に努力しているか，なお

$$
y-y^{\prime}=\Sigma a\left(x-x^{\prime}\right)
$$

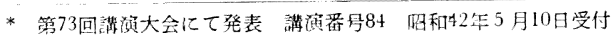

